\title{
ANALISIS TEKSTUAL BRAND TELUK LOVE MENJADI DESTINASI WISATA POPULER DI KABUPATEN JEMBER
}

\author{
Ari Susanti \\ Program Studi Ilmu Komunikasi Universitas Muhammadiyah Jember \\ Email : ari.susanti@unmuhjember.ac.id
}

\begin{abstract}
Love Bay, which is located in Payangan Hamlet, Sumberrejo Village, Ambulu District, Jember Regency, is one of the most popular tourist destinations today. The word "Love" is taken from English which means love. The bay shape which resembles a heart is the first thing why the name of "Love Bay" is given to. Why is the Love Bay Brand chosen, among many words like Teluk Cinta, Teluk Hati, Teluk Asmara and others? Therefore, the researcher is interested in analyzing the Brand of Love Bay. This research entitled Textual Analysis of the Brand of Love Bay Becomes a Popular Tourist Destination in Jember Regency was studied using a qualitative descriptive approach using textual analysis techniques. The results of this study are the word "love" in Love Bay has a higher prestige value because it is considered slang and contemporary. From the business perspective, the word "love" is easier to remember as a product brand, it also has a higher selling value because it is very familiar to the public, especially young the juvenile. In addition, the society's perceptions of the word "love" vary in giving rise for the high curiosity and the major attraction for tourists on visiting Love Bay. The role of social media has become one of the factors of success in branding Love Bay as the popular tourist destination in Jember Regency.
\end{abstract}

\section{Keywords: Textual analysis, brand, a tourist destination}

\begin{abstract}
Abstrak
Teluk Love yang berlokasi di Dusun Payangan Desa Sumberrejo Kecamatan Ambulu Kabupaten Jember menjadi salah satu destinasti wisata popular saat ini. Kata "Love" diambil dari Bahasa Inggris yang berarti cinta. Bentuk teluk yang menyerupai hati inilah yang menjadi awal diberikannya nama Teluk Love. Diantara banyak kata seperti Teluk Cinta, Teluk Hati, Teluk Asmara dan lain-lain, mengapa Brand Teluk Love yang terpilih. Oleh karenanya, peneliti tertarik untuk menganalisis Brand Teluk Love. Penelitian ini berjudul Analisis Tekstual Brand Teluk Love Menjadi Destinasi Wisata Populer Di Kabupaten Jember, diteliti menggunakan pendekatan deskriptif kualitatif dengan menggunakan teknik analisis tekstual. Hasil penelitian ini adalah kata "love" pada Teluk Love memiliki nilai prestise lebih tinggi karena dianggap gaul dan kekinian. Dilihat dari perspektif bisnis, kata "love" lebih mudah diingat sebagai brand sebuah produk, juga memiliki nilai jual lebih tinggi karena sangat akrab di telinga masyarakat terutama anak muda. Selain itu, persepsi masyarakat tentang kata "love" beragam, sehingga menimbulkan rasa ingin tahu tinggi dan menjadi daya tarik utama wisatawan untuk mengunjungi Teluk Love. Peran media sosial menjadi salah satu faktor keberhasilan membranding Teluk Love ini menjadi destinasi wisata popular di Kabupaten Jember.
\end{abstract}

Kata Kunci : Analisis Tekstual, Brand, Destinasi Wisata, Teluk Love 


\section{Pendahuluan}

Pantai Payangan yang terletak di Dusun Payangan Desa Sumberrejo Kecamatan Ambulu Jember merupakan destinasi wisata yang relatif baru dikenal masyarakat. Pantai Payangan dikenal sejak ekspos media sosial yang menampilkan bentuk teluk yang menyerupai gambar hati atau daun waru. Bentuk hati ini yang menyebabkan banyak wisatawan yang mengunjungi pantai tersebut dan mengabadikan dalam bentuk gambar atau foto dengan mengambil angle dari atas bukit yang berada di sebelah barat pantai. Destinasi wisata ini menyedot perhatian wisatawan muda untuk mengabadikan momen tersebut untuk berbagi cinta.

Seperti pantai pada umumnya, Pantai Payangan memiliki pasir putih dan bersih dengan arus ombak cenderung kuat karena menghadap langsung ke Samudra Hindia. Sebagai destinasi wisata baru, Pantai Payangan terus berbenah. Pembangunan fasilitas pendukung objek wisata dalam penggarapan di bawah pengawasan masyarakat setempat. Manajemen wisata Pantai Payangan belum terorganisir dengan baik. Wisatawan lebih tertarik menikmati pemandangan Teluk berbentuk hati dari atas bukit.
Bentuk teluk yang menyerupai bentuk hati ini kemudian lebih dikenal dengan Teluk Love. Sejak nama Teluk Love diviralkan di media sosial, masyarakat semakin penasaran dengan Teluk love ini. Nama love mempunyai daya tarik yang luar biasa bagi pengunjung Pantai Payangan. Diantara banyak nama seperti Teluk Cinta, Teluk Hati, Teluk Asmara dan lain-lain, yang mampu merepresentasikan bentuk hati, mengapa brand Teluk Love yang terpilih.

Penggunaan Brand Teluk Love membawa Pantai Payangan menjadi destinasi wisata yang membuat calon pengunjung penasaran tetang keberadaan. Wisatawan tentu ingin melihat keotentikan bentuk love di Pantai Payangan. Ditinjau dari prespektif Humas, brand Teluk Love memiliki nilai jual karena lebih kekinian dan mudah diingat. Brand Teluk Love yang menjadi viral di media sosial akan memudahkan masyarakat untuk membina hubungan baik dengan stakeholder lainnya sehingga dapat memajukan destinasi wisata Pantai Payangan. Dengan perkembangan teknologi telekomunikasi saat ini, wisatawan ingin mengabadikan segala aktivitasnya dalam memori digital dan disebarluaskan melalui media sosial sebagai media eksistensi diri dan 
aktualisasi diri. Oleh karena itu, peneliti ingin mengkaji fenomena tersebut dengan lebih jauh melalui analisis tekstual brand Teluk Love menjadi destinasi wisata popular di Kabupaten Jember.

\section{Metode Penelitian}

Metode penelitian yang digunakan dalam penelitian ini adalah deskriptif kualitatif. Deskriptif yang dimaksud penelitian ini akan menjabarkan secara sistematis, faktual dan akurat tentang fakta-fakta dan sifat-sifat objek penelitian. Sedangkan kualitatif berupaya menganalisis secara holistik dan memberikan kesempatan seluas-luasnya kepada peneliti untuk mengalih data sebanyak-banyaknya sehingga diperoleh data yang lebih mendalam dan komprehensif.

Fokus penelitian ini adalah brand atau nama Teluk Love yang akan dianalisis secara tekstual. Dalam analisis tekstual akan mengkaji lebih dalam tentang tanda, makna konotasi dan kodekode, makna denotasi dan mitos. Teks yang dimaksud dalam penelitian ini adalah makna "love" pada Teluk Love memiliki banyak kombinasi tanda. Menurut Thwaites, dkk, is anything which produces meanings (tanda adalah segala suatu yang menghasilkan makna. (2002;
9) Dengan demikian, akan banyak makna yang melekat pada brand Teluk Love baik secara individu maupun sosial.

Dalam mengumpulkan data, peneliti menggunakan beberapa teknik sebagai berikut :

1). Wawancara mendalam/in dept interview. Wawancara dilakukan kepada beberapa narasumber yang berkaitan dengan eksistensi Teluk Love seperti Dinas Pariwisata Kabupaten Jember, tokoh masyarakat di dusun Payangan dan testimoni masyarakat untuk melengkapi data sekunder penelitian ini.

2). Observasi. Kunjungan dilakukan untuk melihat lebih dekat operasionalisasi wisata di Teluk Payangan.

3). Foto dokumentasi sebagai dokumen penunjang kelengkapan penelitian.

Analisis data penelitian kualitatif pada dasarnya dikembangkan dengan maksud memberikan makna (making sense of) terhadap data, menafsirkan (interpreting) atau mentransformasikan (transforming) data ke dalam bentukbentuk narasi yang kemudian mengarah pada temuan yang bernuansa proposisiproposisi ilmiah (thesis) yang akhirnya sampai pada kesimpulan-kesimpulan final. (Pawito, 2007, 101)

Kajian penelitian ini melihat hubungan antara teks yang satu dengan 
teks yang lain. Makna tidak memiliki sumber keaslian tunggal, namun ia adalah hasil hubungan antar teks yaitu intertekstualitas (Barker, 2000; 75). Teks juga interdepedensi yang artinya teks tidak semata dimakani tunggal tetapi adalah banyak factor yang melatarbelakanginya sehingga makna yang muncul adalah makna yang sudah holistik dan universal. Seperti dalam penelitian ini, teks pertama yang dilihat adalah nama Teluk Love, teks berikutnya makna Teluk Love dikorelasikan dengan pandangan masyarakat tentang memaknai kata Love dan dampak branding terhadap nama tersebut di masyarakat.

\section{Hasil dan Pembahasan}

\section{1). Analisis Tekstual}

Analisa tekstual merupakan analisis yang bergerak dari tanda-tanda terkecil yang spesifik menuju ke mitos-mitos sosial. Berikut gambaran alur analisis tekstual :

\section{TEXTUAL ANALYSIS}

\section{Signs $\rightarrow$ Connotations and Codes $\rightarrow$ Denotations $\rightarrow$ Myths}

Gambar 1. Textual Analysis

Sumber : Thwaites, Davis, Mules, 2002, Introducing Cultural and Media Studies, New York, Palgrave Publishing, hal. 84
Dari model di atas dapat dipahami bahwa tanda-tanda (tertentu) akan membentuk banyak makna dalam pengertian konotasi dan denotasi yang ada dalam masyarakat pada akhirnya menjadi mitos. Signs dibentuk oleh signifier dan signified dimana signifier adalah petanda sedangkan signified adalah penanda. Tanda akan meTanda-tanda inilah yang membentuk konotasi dan kode-kode. Konotasi selalu berhubungan dengan kode-kode sosial dimana teks tercipta dalam suatu masyarakat. Kode-kode sosial dilatarbelakangi oleh produser dan pembaca teks dimana dalam prosesnya pemaknaan diantara kedua dipengaruhi oleh lingkungan sosial teks terbentuk. Denotasi merupakan tanda yang bersifat stabil karena merupakan representasi dari mitos kultural, kepercayaan, cara pandang dan keyakinan yang telah diyakini kebenarannya oleh masyarakat.

Dalam penelitian ini, difokuskan pada makna brand Teluk Love. Teluk Love terdiri dari dua kata yaitu teluk dan love. Pengertian teluk dalam Kamus Umum Bahasa Indonesia adalah laut yang masuk ke darat (Purwadarminta, 1991; 1039). Sebagai negara kepulauan, adalah wilayah Indonesia memiliki banyak teluk. Struktur daratan Indonesia yang tidak 
beraturan membuat beberapa bibir pantai membentuk teluk yang unik dan indah.

Kata love, diambil dari bahasa Inggris yang artinya cinta. Ada pertanyaan kecil dalam benak peneliti, mengapa memilih kata "love" dari Teluk Love dan bukan memilih kata "cinta" menjadi Teluk Cinta atau kata "hati" menjadi Teluk Hati, dan masih banyak pilihan kata lain untuk merepresentasikan teluk yang berbentuk hati ini. Bila dikaji lebih mendalam, masyarakat menyukai bahasa Indonesia dipasangkan dengan bahasa Inggris. Penggunaan bahasa campuran ini memiliki nilai prestise lebih tinggi karena dianggap gaul dan kekinian. Dilihat dari perspektif bisnis, kata "love" lebih mudah diingat sebagai brand sebuah produk, juga memiliki nilai jual lebih tinggi karena sangat akrab di telinga masyarakat terutama anak muda. Selain itu, persepsi masyarakat tentang kata "love” beragam, sehingga menimbulkan rasa ingin tahu tinggi dan menjadi daya tarik utama wisatawan untuk mengunjungi Teluk Love.

Cinta diartikan sebagai selalu teringat dan terpikir di hati lalu berarti (Purwadarminta, 1991: 206). Kemudian cinta digambarkan dengan berbentuk hati seperti daun waru. Berdasarkan sejarah, bentuk hati bermula dari daun ivy (yang

menyerupai bentuk hati) sebagai symbol cinta abadi pada masyarakat Yunani dan Romawi.

Teluk Love merupakan tanda yang tampak sebagai identitas yang melekat pada Pantai Payangan. Dalam analisis tekstual, "the basic premise of textual analysis is that all signifiers have multiple signifieds." (Thwaites, dkk, 2002; 84) Love sebagai signifier dalam penelitian memiliki arti cinta, sedangkan signifieds diwakili dengan bentuk love yang disimbolkan dengan bentuk hati. Bentuk teluk yang menyerupai hati inilah yang membuat Pantai Payangan mendapatkan julukan Teluk Love. Visualisasi indah teluk, dapaat dilihat dari Bukit Domba yang letaknya tidak jauh dari Pantai Payangan. Berikut adalah gambar Teluk Love diambil dari Bukit Domba :

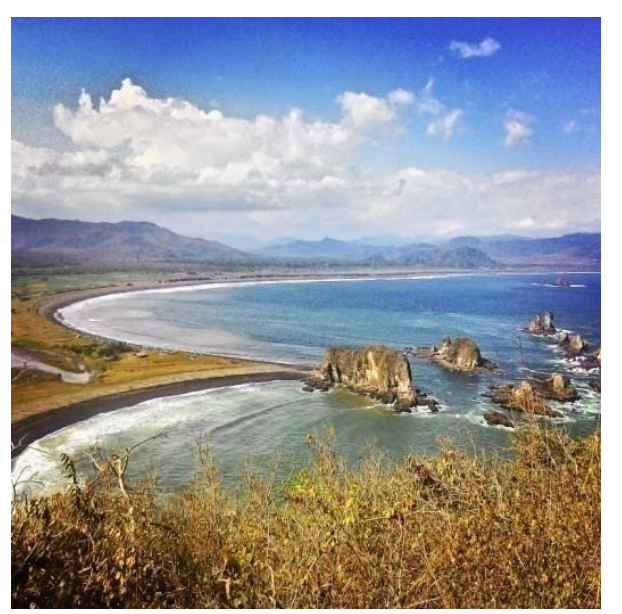

Gambar 2. Foto Teluk Love http://www.ayuniverse.com/2017/09/pant ai-payangan-surga-kecil-di-kampung.html diunggah tanggal 5 September 2018 
Sebuah tanda terkadang memiliki banyak makna. Begitu juga kata love atau cinta memiliki banyak penafsiran. Teluk Love dapat dimaknai sebagai teluk yang mempertemukan cinta, dan atau menyatukan cinta, bahkan melanggeng cinta bagi mereka yang mengunjungi Teluk tersebut. Cinta yang dibangun adalah cinta kepada yang terkasih seperti kepada kekasih atau pasangan (belum menikah), kepada suami atau istri, kepada anak dan keluarga, kepada sahabat dan rekan kerja, bahkan cinta kepada Sang Pencipta atas karya indahNya yang dapat dinikmati masnusia. Oleh karena itu, persepsi masyarakat ketika mendengar Teluk Love akan berbeda-beda disesuaikan dengan kerangka pengetahuan dan pengalaman yang dimiliki masing-masing.

Inilah yang membuat signs (tanda) mulai bergerak ke arah pemaknaan connotation (konotasi). Konotasi yang dimaksud selalu dihubungkan dengan kode-kode yang memiliki makna sosial. Dalam penelitian ini, pemaknaan Teluk Love telah bergeser. Nama Teluk Love yang awalnya terinspirasi dari bentuk teluk yang menyerupai bentuk hati bergeser menjadi love dalam arti yang lebih luas bahkan ada yang memaknai secara negatif misalnya memasukkan unsur mistik, mesum dan sebagainya. Pemaknaan konotasi negatif pada kata Love ini juga didasari frame of reference and frame of experience masyarakat yang berbeda-beda. Di sisi lain, love dimaknai positif oleh masyarakat bahwa Teluk Love membawa banyak cinta bagi para pengunjungnya.

Perbedaan antara konotasi positif dan negatif pada Teluk Love tidak akan memungkiri bahwa Teluk Love berbentuk hati. Hati yang dimaksud Aristoteles adalah jantung dimana jantunglah pusat pikiran dan emosi manusia. Tanpa jantung, manusia mati. Pada akhirnya, mitos yang berkembang di masyarakat adalah Teluk Love tidak hanya teluk yang berbentuk hati tetapi juga memancarkan energi cinta positif pada siapapun yang berkunjung.

\section{Branding dan Public Relations pada Teluk Love}

Pantai Payangan banyak dikunjungi wisatawan setelah nama Teluk Love menjadi bahan perbincangan popular di media sosial sekitar 3 tahun terakhir. Masyarakat sangat antusias dan penasaran akan keindahan alam Teluk yang berbentuk hati ini. Peneliti mengkonfirmasi hal tersebut kepada Frans Sembiring selaku staf pengembangan 
produk Dinas Pariwisata dan Kebudayaan Kabupaten Jember mengatakan "Dari dulu namanya Pantai Payangan dan bukan Teluk Love. Dinas Pariwisata sendiri mempublikasikan objek wisata tersebut dengan nama aslinya yaitu Pantai Payangan".

Selama ini, Dinas Pariwisata Kabupaten Jember telah mempublikasikan Pantai Payangan sebagai salah satu objek wisata potensial di Jember. Tetapi dilihat dari jumlah kunjungan tidak sebanyak Pantai Papuma dan Pantai Watu Ulo yang terletak tidak jauh dari Pantai Payangan. Objek wisata ini baru menjadi viral setelah nama Pantai Payangan lebih terekspos dengan nama Teluk Love.

Upaya masyarakat Dusun Payangan dengan membranding Teluk Love merupakan aktivitas public relations. Menurut Yunus, Angeline dan Ramadanty mengatakan “...sekarang peran public relations telah berkembang dengan batasbatas yang lebih luas. Kini kegiatan public relations, periklanan dan komunikasi pemasaran bersatu menjadi public relations dan branding." (2017; 173) Perubahan ini terjadi karena respon terhadap lingkungan bisnis bergerak dinamis.
Dalam perspektif periklanan, brand tidak hanya simbol atau nama produk saja tetapi juga harus mudah diingat sesuai dengan visi dan misinya serta prinsip perusahaan. Istilah love dalam Teluk Love mampu merepresentasikan banyak hal seperti keindahan, keagungan, kekeluargaan, dan keramahan sekaligus. Selain itu, kata love mengandung unsur energik, kekinian dan gaul. Sehingga Teluk Love mudah mendapatkan perhatian bahkan memunculkan rasa penasaran masyarakat. Paket komplit brand Teluk Love telah berhasil membawa Pantai Payangan menjadi destinasi wisata potensial Jember.

Frans Sembiring menambahkan bahwa nama Teluk Love tidak digagas oleh Dinas Pariwisata tetapi pengunjung yang memberikan julukan cantik ini dan kemudian oleh masyarakat setempat diamini dan diekspos di media sosial. Karenanya, Teluk Love tidak dikelola di bawah naungan Pemerintah Daerah Kabupaten Jember melainkan masyarakat sekitar yang mengelola secara mandiri sebagai mata pencaharian utama. Maka dari itu, pembangunan infrastruktur sekitar Teluk Love belum tertata dan terorganisir dengan baik. Ketika peneliti menanyakan apakah ke depan Pantai Payangan ini akan mendapat suntikan 
dana pembangunan area wisata, umum belum menjangkau daerah sementara ini Pemerintah Kabupaten tersebut. Sebaiknya menggunakan Jember dan Dinas Pariwisata sedang kendaraan pribadi.

menggodok kemungkinan tersebut.

Terlepas dari infrastruktur Teluk Love yang belum memadai, minat wisatawan untuk mengunjungi objek wisata ini cenderung meningkat. Ada beberapa hal yang menyebabkan meningkatnya kunjungan wisatawan ini antara lain :

1). Harga tiket murah meriah. Dengan merogoh kocek Rp 5.000,- (lima ribu rupiah), pengunjung dapat melihat keindahan Teluk Love dari bukit domba. Biaya lain yang harus dikeluarkan pengunjung adalah biaya parkir kendaraan. Biaya parkirnya pun relative terjangkau.

2). Objek wisata masih alami, belum pembangunan dan objek wisata buatan. Keaslian alam menjadi daya tarik bagi wisatawan.

3). Wisata kuliner dengan hidangan laut yang segar menjadi tujuan wisatawan. Selain menyaksikan pemandangan alam, banyak warung-warung di Teluk Love yang menyajikan wisata kuliner seperti kepiting, lobster, gurita dan ikan-ikan segar lainnya.

4). Akses jalan menuju ke objek wisata dalam kondisi baik. Namun transportasi

\section{3). Peran Media dalam Mengangkat}

\section{Branding Teluk Love}

Keberhasilan masyarakat Payangan dalam membranding Teluk Love berkat bantua media terutama media sosial. Secara sadar dan berkala, mereka mempromosikan Teluk Love terutama dengan mengunggah pemandangan indah Teluk yang berbentuk hati. Upaya ini membawa hasil. Pengunjung pun mulai ikut membantu memviralkan objek wisata tersebut melalui akun pribadinya. Banyak juga blog yang memberikan ulasan tentang objek wisata ini. Belakangan ini, bagi masyarakat aktivitas media sosial merupakan gaya hidup jaman now. Menurut Alfathri, dkk (2015; 36), "Gaya hidup dipahami sebagai adaptasi aktif individu terhadap kondisi sosial dalam rangka memenuhi kebutuhan untuk menyatu dan bersosialisasi dengan orang lain." Sebagai individu, manusia membutuhkan pengakuan publik atas eksistensi dirinya. Dengan teknologi, pengakuan publik dapat diwujudkan dengan mudah yaitu melalui media sosial. Masyarakat jaman now, banyak mengunggah foto-foto aktivitas sehari- 
hari sebagai kegiatan rutin yang wajib hukumnya. Terlebih jika mengunggah spot foto bagus dan masih belum banyak yang mengunggah maka mereka akan menjadi inovator, leader dengan banyak followers.

Hal senada juga disampaikan oleh Narno Nadias selaku peraih penghargaan Pemuda Pelopor Nasional di bidang Seni Budaya pada tahun 1992 dan tahun 1993 bahwa tidak ada yang istimewa dari Pantai Payangan atau Teluk Love. Pada prinsipnya tidak ada perubahan struktur pantai dan teluk. Dari dulu tetap sama. Oleh karenanya, Teluk Love sering dijadikan tempat mencari inspirasi karyakarya seni bahkan lokasinya sangat mendukung untuk pendalaman latihan teater. Menurut Pak Narno, Pantai Payangan menjadi destinasi wisata popular saat ini karena media sosial berperan besar dalam memviralkan keindahan pemandangan Teluk Love. Dibandingkan dengan era sebelum teknologi android, foto dibuat untuk kepentingan pribadi atau kelompok. Tapi sekarang semua diunggah di media sosial. Mengunggah foto di media sosial merupakan aktivitias rutin yang tidak dapat dipisahkan dengan masyarakat jaman now. Promosi melalui "gethok tular" atau testimoni ini yang menjadi kunci sukes membranding Teluk Love melalui media sosial.

Pemanfaatan media sosial sebagai ujung tombak pemasaran merupakan langkah jitu yang diambil oleh masyarakat Payangan dalam mempromosikan Teluk Love. Besarnya jumlah pengguna media sosial ikut andil kesuksesan ini. Di samping itu, masyarakat Indonesia cenderung menggunakan alat komunikasi yang up to date karena menggunakan alat komunikasi yang canggih dalam hal ini smartphone merupakan bagian dari gaya hidup. Sehingga masyarakat dengan mudah mendapatkan akses di media sosial yang memberikan informasi terkini, mengirimkan data, foto bahkan video. Fitur kamera canggih yang dimiliki smartphone, menghasilkan kualitas gambar yang jernih. Inilah yang banyak digunakan oleh pengguna media sosial di Indonesia.

Kondisi ini dapat dikategorikan masyarakat telah kecanduan media sosial. Mereka tidak bisa beraktivitas tanpa smartphone hingga mereka merasa lebih baik ketinggalan dompet daripada ketinggalan smartphone. Kecenderungan masyarakat yang demikian, dimaksimalkan oleh masyarakat dan pengunjung untuk membranding Teluk 
Love dengan harapan objek tersebut dikenal banyak orang. Kekuatan dari Teluk Love ini adalah keunikan geografis teluk yang berbentuk hati sangat mudah dijual di media. Brand Teluk Love mudah dingat. Brand Teluk Love membentuk pencitraan yang baik di mata masyarakat dimana love atau cinta memiliki makna dan persepsi yang beragam dan cenderung memiliki pesan yang positif.

Siapapun tahu bahwa cinta disimbolkan dengan bentuk hati. Siapapun yang pernah berkunjung ingin menunjukkan cintanya dengan keindahan Teluk Love sebagai latarnya. Dan siapapun ingin berbagi momen kebahagiaan melalui akun pribadi.

\section{Simpulan}

Berdasarkan hasil analisa penelitian dapat disimpulkan bahwa kata "love" pada Teluk Love digagas oleh pengunjung Pantai Payangan yang mengagumi keindahan alam. Kata "love" juga mudah diingat meskipun dalam bahasa Inggris. Dari perspektif bisnis, kata "love" lebih menjual karena sangat akrab di telinga masyarakat terutama anak muda. Selain itu, penggunaan bahasa Inggris memiliki nilai prestise relatif lebih tinggi dibandingkan dengan menggunakan brand dengan nama
Indonesia. Kekuatan kata "love" mampu membranding Teluk Love dengan sempurna. Persepsi masyarakat tentang kata "love" beragam, sehingga menimbulkan rasa penasaran dan menjadi daya tarik utama wisatawan untuk mengunjungi Teluk Love.

Peran media sosial menjadi salah satu faktor keberhasilan membranding Teluk Love ini. Kecenderungan masyarakat Indonesia yang gemar berswafoto dan mengunggahnya ke media sosial menjadi ujung tombak promosi "gethok tular" (testimoni) ini.

\section{Daftar Pustaka}

\section{Buku :}

Adlin, Alfathri, dkk, 2015, Resistensi Gaya Hidup : Teori dan Realitas, Yogyakarta, Jalasutra

Barker, Chris, 2006, Cultural Studies Teori dan Praktek, diterjemahkan oleh Nurhadi, Kreasi Wacana, Yogyakarta

Pawito, 2007, Penelitian Komunikasi Kualitatif, LKiS Pelangi Aksara, Yogyakarta

Purwadarminta, WJS, 1991, Kamus Umum Bahasa Indonesia, Balai Pustaka, Jakarta 
Thwates Tony, Llyod Davis dan Warwick

Mules, 2002, Introducing Cultural and Media Studies - A Semiotic Approach, New York Palgrave Publishing

Yunus, Ulani, Mia Angeline dan Sari Ramadanty, 2017, Advertising \& Branding, Jakarta, Penerbit Edu

Pustaka

\section{ri} du

\section{Internet :}

http://www.ayuniverse.com/2017/09/pant ai-payangan-surga-kecil-di-kampung.html diunggah tanggal 5 September 2018 